\title{
Start-up and operating costs for artisan cheese companies
}

\author{
Andrea Bouma, ${ }^{*}$ Catherine A. Durham, $\dagger$ and Lisbeth Meunier-Goddik ${ }^{1}$ \\ *Department of Food Science and Technology, Oregon State University, Corvallis 97331 \\ †Department of Applied Economics, Food Innovation Center, Oregon State University, Portland 97209 \\ $\ddagger$ Department of Food Science and Technology, Oregon State University, Corvallis 97331
}

\begin{abstract}
Lack of valid economic data for artisan cheese making is a serious impediment to developing a realistic business plan and obtaining financing. The objective of this study was to determine approximate start-up and operating costs for an artisan cheese company. In addition, values are provided for the required size of processing and aging facilities associated with specific production volumes. Following in-depth interviews with existing artisan cheese makers, an economic model was developed to predict costs based on input variables such as production volume, production frequency, cheese types, milk types and cost, labor expenses, and financing. Estimated values for start-up cost for processing and aging facility ranged from $\$ 267,248$ to $\$ 623,874$ for annual production volumes of $3,402 \mathrm{~kg}(7,500 \mathrm{lb})$ and $27,216 \mathrm{~kg}(60,000 \mathrm{lb})$, respectively. First-year production costs ranged from $\$ 65,245$ to $\$ 620,094$ for the above-mentioned production volumes. It is likely that high start-up and operating costs remain a significant entry barrier for artisan cheese entrepreneurs.
\end{abstract}

Key words: artisan cheese cost, economic model

\section{INTRODUCTION}

The number of artisan dairy processors has grown significantly over the past decade. For example, in Oregon, the number of artisan dairy companies has risen from 3 to 26 since 1999 (Figure 1). One important factor limiting new company growth is the lack of reliable economic data. Entrepreneurs who start these companies are challenged by the lack of available information on start-up and production costs. This complicates development of credible business plans and makes it difficult to obtain financing.

The few available studies focus on large-scale commodity milk processing (Erba et al., 1997), economic feasibility of small commodity cheese processing fa-

Received November 11, 2013

Accepted February 18, 2014.

${ }^{1}$ Corresponding author: Lisbeth.goddik@oregonstate.edu cilities (Becker et al., 2007), and start-up of artisan companies with no mention of financial considerations (Reed et al., 2011). Although economic data are available for large-scale processors (Ahearn et al., 1987; Papadatos et al., 2002), this is not the case for artisans, and the available data cannot be accurately extrapolated to these smaller scale businesses. Becker et al. (2007) investigated the economic feasibility of a dairy processing facility of varying processing capacities. The smallest scenario investigated was a family farm of 50 cows assumed to produce "an initial volume of 7,938 $\mathrm{kg}(17,500 \mathrm{lb})$ of milk per week for processing." In reality, much smaller volumes are observed in the current artisan cheese industry, where approximately 1,000 to $3,000 \mathrm{~kg}$ of milk per week is found to be more common (Sakovitz-Dale, 2006).

Nicholson and Stephenson (2007) did investigate financial considerations but only, as self-proclaimed, "an initial foray designed to highlight certain issues and pave the way for necessary more comprehensive research projects on value-added dairy processing." Their study on value-added dairy operations in New York, Vermont, and Wisconsin highlighted valuable issues in artisan cheese operations. They concluded that initial capital purchases of plant and equipment must be carefully considered through operation financial analyses; product pricing was a problem, where a minimum of $\$ 22 / \mathrm{kg}(\$ 10 / \mathrm{lb})$ of cheese was necessary to cover operational costs; and that a well-prepared business plan was essential to value-added product success. Another important conclusion made by Nicholson and Stephenson (2007) was that many of the investigated operations transitioned into value-added processing from fluid milk production, and that operators were less likely to "have good understanding of the capital needs to build and operate a small processing plant."

Common financial problems observed with smallscale dairy start-ups are often related to the following areas as listed by Axtell et al. (2008): "[Owners] treating profits as their income instead of paying themselves a salary and investing profits into the business, incorrect costing and pricing of products so that they do not make a profit, poor record keeping so they do not know if they are operating profitably, over-spending or hav- 
Table 1. General categories of questions used for the survey of current artisan cheese companies

\begin{tabular}{lll}
\hline Processing attributes & Start-up costs & Operational costs \\
\hline Milk processing capacity & Equipment sizes/prices & Labor (production and sales) \\
Product attributes and pricing & Overall cost of start-up & Utilities and waste management \\
Total production per year & Facility building costs & Licensing and insurance \\
Facility size & Aging facility building and installation & Ingredients and sanitation liquids \\
Aging facility size & Milk transport equipment & Packaging/labels \\
\hline
\end{tabular}

ing a loan that is not repayable, and having too many debts or creditors."

The objectives of this study were to determine startup and operating costs for artisan cheese producers, in addition to production and aging facility size. An economic model was developed as a tool to forecast costs and revenues, although only costs are presented here. The model was developed based on economic information from 6 existing artisan processors and beta-tested on 3 entrepreneurs within the start-up process. The overall outcome of the study was to help artisan cheese entrepreneurs make credible business decisions.

\section{MATERIALS AND METHODS}

\section{Cheese Company Surveys}

A 57-question survey was used to investigate the financial background of starting and operating an artisan cheese company. Brief descriptions of representative questions that were asked are shown in Table 1. The questionnaires were sent out to company owners electronically and followed up by an in-person interview. Six cheese companies participated in the extensive survey. The data from this survey were used in the design of an interactive business operations model.

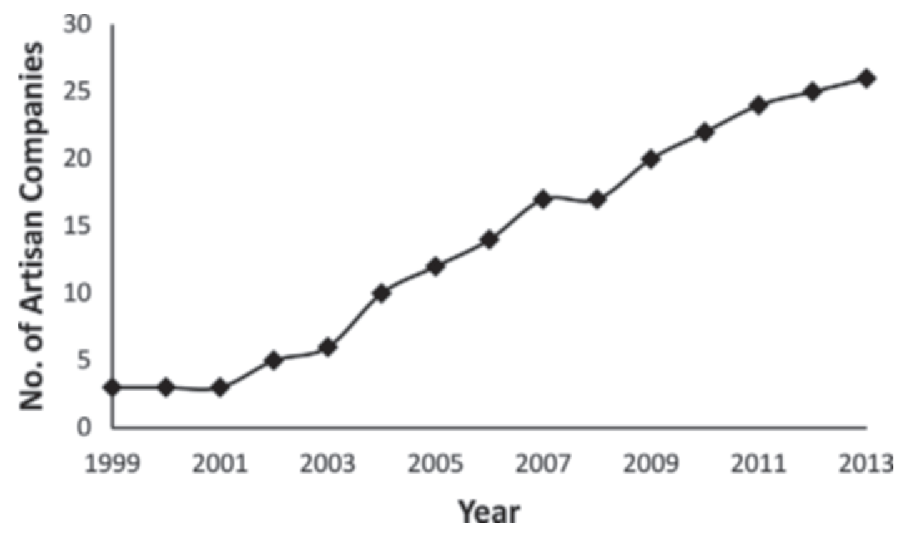

Figure 1. Number of artisan cheese companies in Oregon. Data obtained from Oregon Department of Agriculture dairy plant licenses.

\section{Business Model and Development}

Survey data were used in the design of the operating business model in Excel 2010 (Microsoft Corp., Redmond, WA). This software package was chosen because of its widespread availability to potential artisan cheese entrepreneurs. Assumptions used in the model design are summarized in Table 2. The companies surveyed ranged in size from $1,361 \mathrm{~kg}(3,000 \mathrm{lb})$ cheese/yr to $36,287 \mathrm{~kg}(80,000 \mathrm{lb})$ cheese/yr. Therefore, this model should only be utilized for company scenarios that fall within this production range.

Cost of Capital and Discount Rate. The discount rate of $10 \%$ was used to evaluate all financial analyses. This was determined through evaluation of the risk associated with starting a specialty food business. The lowest cost of capital was determined to be debt financing at $6 \%$, and an additional risk of $4 \%$ was added for conservative calculations.

Initial Capital Investment. Initial capital investment estimates were calculated and reported as monthly loan payments. The model calculates the following information as output: initial capital needed for a down payment on the loan, $20 \%$ of principal, and additional capital necessary to operate business during negative cash flow years. The model estimated values for facility size requirements, necessary equipment, and aging room capacity to accommodate the total cheese produced at the end of the last year in the study period (yr 15).

Equipment. Necessary equipment was determined by the survey of artisan cheese companies, and pricing values were based on quotes from various equipment manufacturing companies as well as a dairy equipment installation specialist (H. Schuller, C. van't Riet Dairy Technology, DuBois, PA; personal communication).

Processing Facility. Required facility size was calculated based on data obtained from the survey. Facility sizes (not including aging room or additional areas for tasting and sales) are plotted against total yearly cheese production in Figure 2. The production data collected ranged from approximately $1,361 \mathrm{~kg}(3,000 \mathrm{lb})$ to 36,287 $\mathrm{kg}(80,000 \mathrm{lb})$ total yearly cheese production. As seen from the data points, the relationship between the area needed for the facility and desired capacity was nonlin- 
Table 2. General model assumptions used for model parameter design

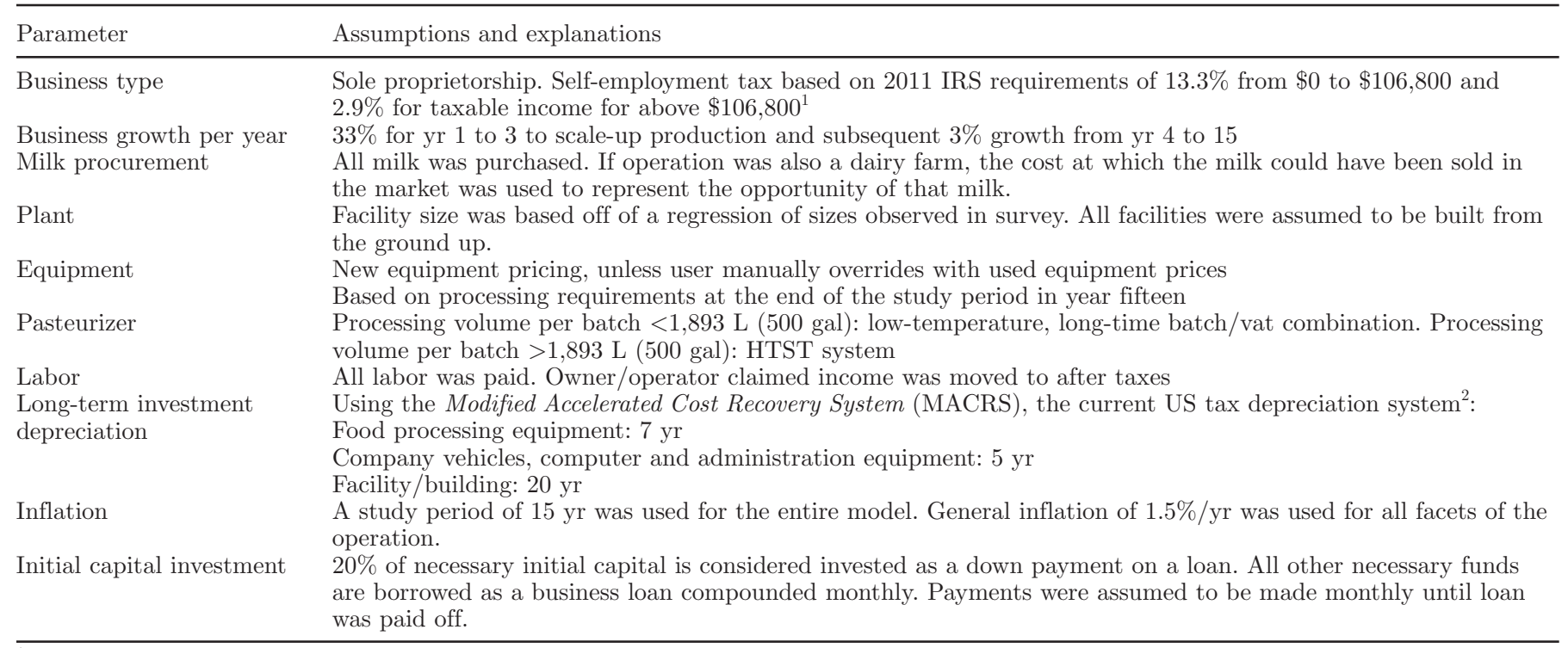

${ }^{1}$ Internal Revenue Service (2011).

${ }^{2}$ Internal Revenue Service (2010).

ear, so several nonlinear relationships were tested. The best of these for these data was the double (natural) log format, where the $y$ and $x$ variables are logged before being regressed using ordinary least squares; thus, log $A_{p}$ (area of processing facility) is regressed on the log of production capacity. The resulting equation in a nonlog form is shown in equation [1b]. Although information was limited to 6 plants, a good fit between plant size and capacity was observed with an $\mathrm{R}^{2}$ of 0.982 . The facility size necessary for the planned capacity is then entered into Equation [1], which calculates the total size and cost of the processing facility building:

$$
\mathrm{C}_{\mathrm{p}}=\text { total cost of processing facility in } \mathrm{m}^{2}=
$$

$$
\$ 1,614.6 \times \mathrm{A}_{\mathrm{p}},
$$

$\mathrm{C}_{\mathrm{p}}=$ total cost of processing facility in $\mathrm{ft}^{2}=$

$$
\$ 150 \times \mathrm{A}_{\mathrm{p}},
$$

where $A_{p}=$ area of processing facility in $\mathrm{m}^{2}=$

$$
2.9954 \times(\mathrm{P})^{0.3866}
$$

and $\mathrm{A}_{\mathrm{p}}=$ area of processing facility in $\mathrm{ft}^{2}=$

$$
23.751 \times(\mathrm{P})^{0.3866}
$$

and $\mathrm{P}=$ total production capacity per year $(\mathrm{kg}$ or $\mathrm{lb})$.
The cost of building the facility was determined through consultation with engineering firms who specialize in fabrication of dairy processing facilities. A cost coefficient of $\$ 1,614.6 / \mathrm{m}^{2}\left(\$ 150 / \mathrm{ft}^{2}\right)$ of processing facility space was used for this calculation as an overall average cost of both processing areas and general construction (Richard Chin, Covert Engineers, Portland, OR; personal communication).

Aging Facility. Aging rooms have specialized costs involved, such as those associated with air manipulation (to control humidity, flow, and temperature). The capacity of the aging facility depends on cheese styles and production levels and was therefore calculated separately within the model. Harder cheeses need a greater aging space due to the longer period of ripening and inventory storage requirements. In contrast, fresh cheeses may not require any aging room but only shortterm cold storage. The survey of current artisan cheese companies resulted in an aging room estimation factor of $0.01096 \mathrm{~m}^{2} / \mathrm{kg}\left(0.0535 \mathrm{ft}^{2} / \mathrm{lb}\right)$ of cheese being aged in the space at one time. This provides the minimum adequate space to maneuver and maintain inventory when production is at full capacity. An assumption of 2.44-m (8-ft) ceilings in the room was used. An expert in the construction of cheese aging rooms (Neville McNaughton, CheezSorce, St Louis, MO; personal communication) was consulted, and various scenarios were evaluated for potential total aging facility fabrication cost. The fixed portion of the equation represents underlying equipment and minimum space. These values were then plotted and analyzed using linear regression 
Estimated Necessary Facility Size

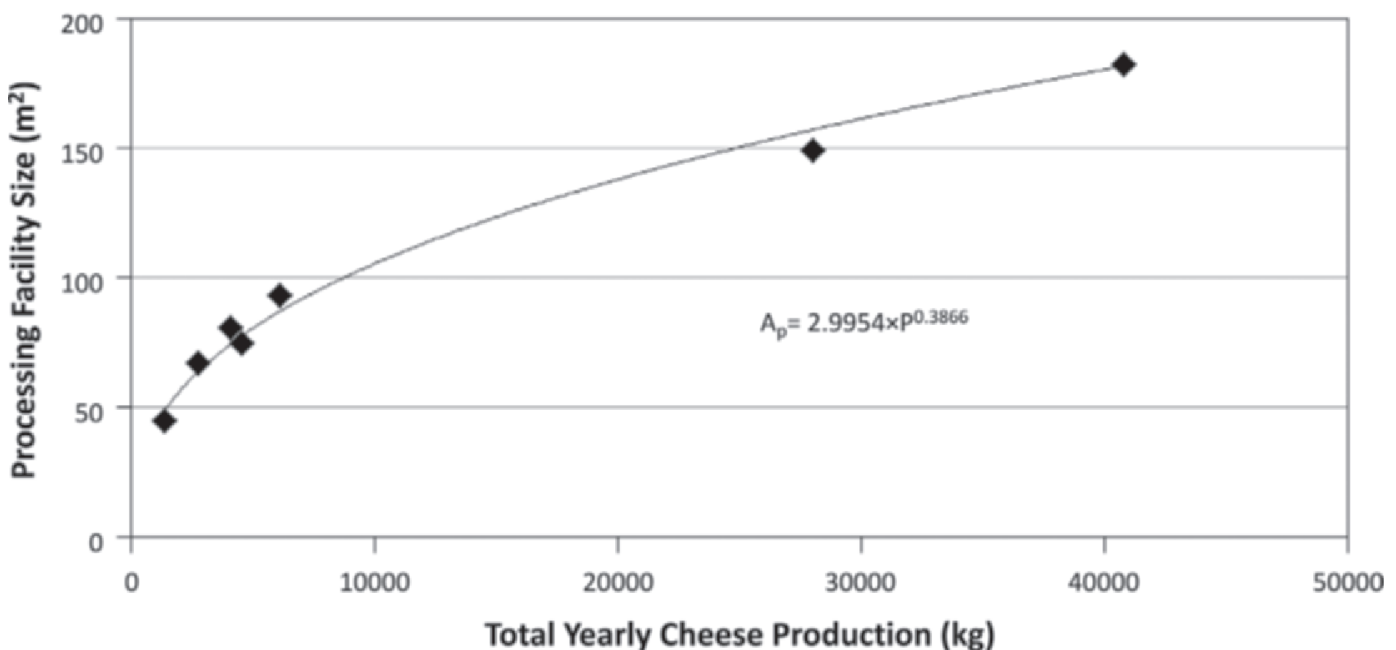

Figure 2. Production facility size $\left(\mathrm{m}^{2}\right)$ required to process $1 \mathrm{~kg}$ of cheese at different total production volumes. $\mathrm{A}_{\mathrm{p}}=$ area of processing facility; $\mathrm{P}=$ total production of cheese per year. Results from survey data used to determine the necessary facility size calculation in model.

to result in Equation [2], which was used in the model to determine aging facility area necessary per kilogram or pound of cheese in the aging room at any one time and final cost of building an aging facility $\left(\mathrm{C}_{\mathrm{a}}\right)$ :

$$
\begin{aligned}
& \mathrm{C}_{\mathrm{a}}=\text { total cost of aging facility in } \mathrm{m}^{2}= \\
& \qquad \begin{array}{c}
288.53 \times\left(\mathrm{A}_{\mathrm{a}}\right)+24,074, \\
\mathrm{C}_{\mathrm{a}}=\text { total cost of aging facility in } \mathrm{ft}^{2}= \\
26.805 \times\left(\mathrm{A}_{\mathrm{a}}\right)+24,074,
\end{array}
\end{aligned}
$$

where $A_{a}=$ area of aging facility in $\mathrm{m}^{2}=$

$$
0.01096 \times \mathrm{P}_{\mathrm{a}}
$$

and $\mathrm{A}_{\mathrm{a}}=$ area of aging facility in $\mathrm{ft}^{2}=0.0535 \times \mathrm{P}_{\mathrm{a}}$,

and $\mathrm{P}_{\mathrm{a}}=$ total production in aging facility at one time ( $\mathrm{kg}$ or $\mathrm{lb})$.

Operating Expenses. Survey results identified the most important costs associated with operation of an artisan cheese business. The model was programmed to include calculation for each of the operating costs listed in Table 3.

Labor. Three types of labor were calculated: managerial $\left(\mathbf{L}_{\mathrm{m}}\right)$, retail $\left(\mathbf{L}_{\mathbf{r}}\right)$, and production $\left(\mathbf{L}_{\mathrm{p}}\right)$. Both $\mathrm{L}_{\mathrm{m}}$ and $\mathrm{L}_{\mathrm{r}}$ were estimated using hourly wages of $\$ 20.00$ and $\$ 10.00 / \mathrm{h}$, respectively. Production labor was a salaried full-time position and hired at $\$ 45,000 /$ yr. All labor necessary for production was allocated, including that of the owner/operator. It was assumed that the owner would be working each week in the following functions: $10 \mathrm{~h}$ in management roles, $20 \mathrm{~h}$ in production, and 10 $\mathrm{h}$ in retail sales. The total owner labor cost was then accounted for and removed as an expense after business taxes were calculated because the business enterprise is assumed to be classified as a sole proprietorship. A factor of 1.3 increased each set labor rate to account for additional benefits and expenses involved in having paid employees.

Managerial labor was defined as the time spent creating a place for the products within all 3 revenue markets (retail, wholesale, and distribution). Equation [3] included factors that affected required managerial hours:

$\mathrm{L}_{\mathrm{m}}=\left(52 \times \mathrm{t}_{\mathrm{md}}+52 \times \mathrm{t}_{\mathrm{mw}}+\mathrm{t}_{\mathrm{mf}}\right) \times \$ 20.00 \times 1.3, \quad[3]$

where $t_{\mathrm{md}}=$ time spent managing distributor sales weekly $(1 \mathrm{~h} /$ distributor $) ; \mathrm{t}_{\mathrm{mw}}=$ time spent managing wholesale retailers weekly $(0.25 \mathrm{~h} /$ retailer/restaurant); and $\mathrm{t}_{\mathrm{mf}}=$ time spent managing direct sales through farmers' markets ( $4 \mathrm{~h} / \mathrm{d}$ at farmers' market), serving dual purposes of marketing the company's story and sales.

Retailing labor was directly connected to the number of hours spent participating in farmers' markets and driving deliveries of product to retailers and restaurants for the wholesale market. Equation [4] included factors that affected retail labor: 
Table 3. Operating costs used in the model

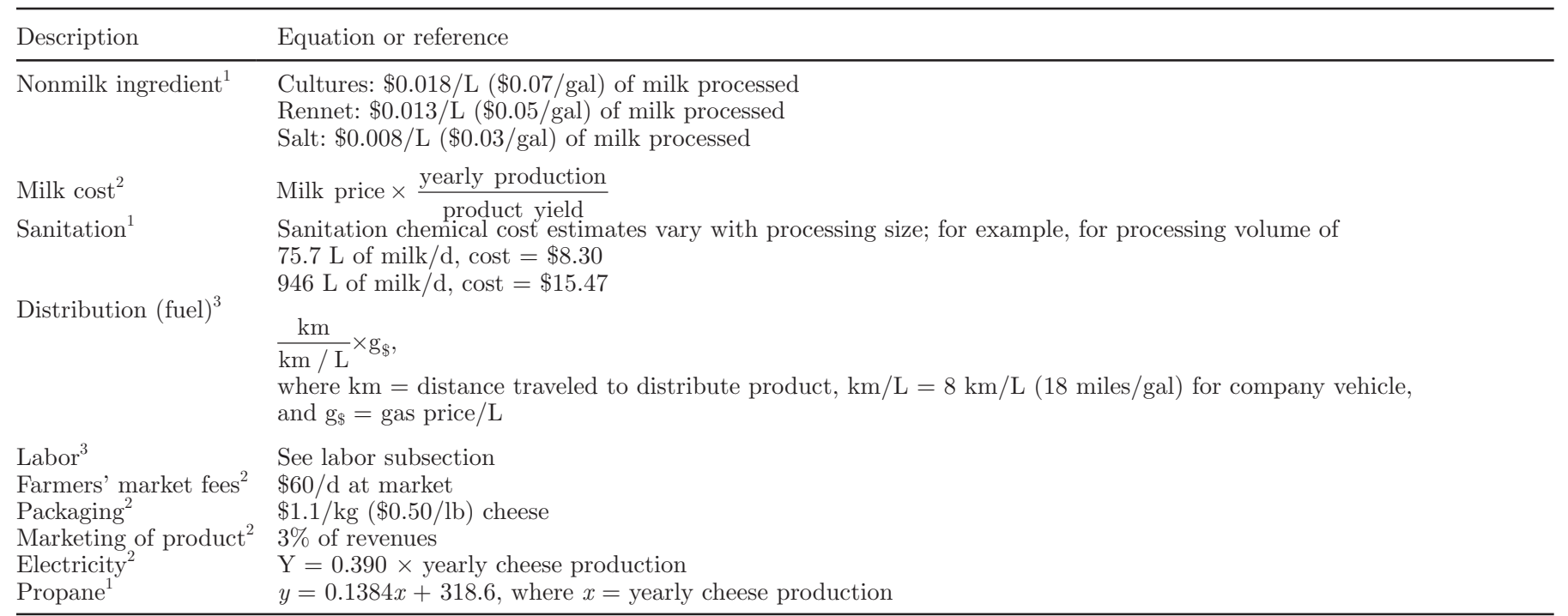

${ }^{1}$ Sourced by industry supplier quotes; should be updated regionally.

${ }^{2}$ Artisan cheese company survey result; should be updated regionally.

${ }^{3}$ Variable in model that can be modified by users.

$$
\mathrm{L}_{\mathrm{r}}=\left(\mathrm{t}_{\mathrm{rf}}+\mathrm{t}_{\text {rdrive }}\right) \times \$ 10.00 \times 1.3,
$$

where $\mathrm{t}_{\mathrm{rf}}=9 \mathrm{~h} / \mathrm{d}$ at farmers' market (nondriving); $\mathrm{t}_{\mathrm{rdrive}}$ $=$ total driving time $\left(\mathrm{t}_{\mathrm{d}}\right)=\mathrm{km}_{\mathrm{t}} /\left(\mathrm{km} / \mathrm{h}_{\text {avg }}\right)$, where $\mathrm{km}_{\mathrm{t}}$ $=$ total $\mathrm{km}$ to deliver products to wholesale and farmers' markets $/ \mathrm{yr}$, and $\mathrm{km} / \mathrm{h}_{\mathrm{avg}}=$ average driving rate $=$ $56 \mathrm{~km} / \mathrm{h}(35 \mathrm{mph})$. The total distance to wholesale and farmers' markets was based upon variables of average distances to both farmers' markets and weekly delivery trips to wholesale outlets. For this study, we used values of $322 \mathrm{~km}$ (200 miles)/wk for wholesale deliveries and $97 \mathrm{~km}$ (60 miles)/farmers' market.

Production labor was considered any labor related to the actual processing of artisan cheese, mainly focusing on cheese making days and aging room maintenance. This type of labor was estimated based on 1 full-time employee. Production labor was calculated by using Equation [5]:

$$
\mathrm{L}_{\mathrm{p}}=\left[\left(\mathrm{t}_{\mathrm{pc}}+\mathrm{t}_{\mathrm{pa}}+\mathrm{t}_{\mathrm{pp}}\right) / 40 \mathrm{~h}\right] \times \$ 45,000 \times 1.3,
$$

where $t_{p c}=$ cheese processing time $(8 \mathrm{~h} / \mathrm{d}$ of milk processing); $\mathrm{t}_{\mathrm{pa}}=$ aging cheese maintenance time $[0.00785$ $\mathrm{h} / \mathrm{wk} \times$ total $\mathrm{kg}$ of cheese in aging room at one time $(0.00357 \mathrm{~h} / \mathrm{wk} \times$ total $\mathrm{lb}$. of cheese in aging room at one time)]; and $t_{p p}=$ cheese packaging time [total $\mathrm{kg}$ of cheese $\div 19.2$ (lb. of cheese $\div 40)$ ]. We determined the aging cheese maintenance time $[0.00785 \mathrm{~h} /$ wk per $\mathrm{kg}(0.00357 \mathrm{~h} /$ wk per lb)] from the survey of artisan cheese companies. The same survey of artisan cheese makers indicated that approximately $19.2 \mathrm{~kg}$ (40 lb) of cheese can be packaged per hour.

\section{Model Validation}

To test the accuracy of this tool, sets of representative business operation attributes were input into the model and compared with an actual business with those attributes. This was repeated 3 times with different types of companies to ensure the robustness of the tool.

An example of a change that was made after one of these beta-testing sessions was that a scale-up period of $3 \mathrm{yr}$ was introduced into the design. A potential company was concerned that realistically they would not be able to begin at desired production capacity immediately (yr 1) and that this would throw off the feasibility analysis. A business start-up expert in the cheese industry was consulted and we determined that using a 3-yr scale-up period was appropriate to industry standards.

The usability of the tool itself was validated through multiple meetings with potential start-up company representatives. Since 2012, 12 entrepreneurs and existing cheese makers have used the tool in conjunction with the authors.

\section{RESULTS AND DISCUSSION}

The model was used to investigate 4 scenarios all involving Cheddar cheese, aged for $150 \mathrm{~d}$, produced at total annual production volumes, by yr 3 , of $3,402 \mathrm{~kg}$ $(7,500 \mathrm{lb}), 6,804 \mathrm{~kg}(15,000 \mathrm{lb}), 13,604 \mathrm{~kg}(30,000 \mathrm{lb})$, and $27,216 \mathrm{~kg}(60,000 \mathrm{lb})$. For each scenario, the following parameters were calculated: production facility size, aging room size, building and equipment costs, 
Table 4. Variables in scenarios used in this study

\begin{tabular}{|c|c|}
\hline Variable & Value used \\
\hline \multirow{2}{*}{ Labor } & Manager: $\$ 20.00 / \mathrm{h}$ \\
\hline & Cheese maker: $\$ 45,000 / \mathrm{yr}$ \\
\hline \multirow[t]{3}{*}{ Owner/operator labor per week } & Manager duties: $10 \mathrm{~h}$ \\
\hline & Production: $20 \mathrm{~h}$ \\
\hline & Retail sales: $10 \mathrm{~h}$ \\
\hline \multirow[t]{4}{*}{ Production during yr 3 after scale-up } & Scenario 1: 3,402 kg/yr (7,500 lb/yr) \\
\hline & Scenario $2: 6,804 \mathrm{~kg} / \mathrm{yr}(15,000 \mathrm{lb} / \mathrm{yr})$ \\
\hline & Scenario 3: $13,608 \mathrm{~kg} / \mathrm{yr}(30,000 \mathrm{lb} / \mathrm{yr})$ \\
\hline & Scenario 4: $27,216 \mathrm{~kg} / \mathrm{yr}(60,000 \mathrm{lb} / \mathrm{yr})$ \\
\hline \multirow[t]{3}{*}{ Cheese production days per year } & Scenario 1: 52 \\
\hline & Scenario 2: 104 \\
\hline & Scenario 3: 156 \\
\hline Maximum days at farmers' markets producer would realistically be able to attend per year & 156 (3 d/wk year round) \\
\hline Maximum number of retailer outlets available for wholesales & 15 \\
\hline \multirow[t]{2}{*}{ Product attributes: Cheddar } & Yield: $10 \%$ \\
\hline & Aging: $150 \mathrm{~d}$ \\
\hline
\end{tabular}

and operating costs. Input variables for all scenarios are summarized in Tables 2 and 4. Although this study does not cover revenue, it is important to note that few artisans are successful in producing standard Cheddar cheese. To maximize revenue, artisan cheeses must be unique and different, such as cloth-bound Cheddar.

\section{Costs Associated with Start-Up}

Size and cost of processing and aging facilities for each production volume are summarized in Table 5 . Care should be taken not to assume that the model output data are exact. Many factors can affect each scenario. For example, some entrepreneurs are able to construct the facility on their own, thereby lowering building costs. The scenarios do highlight the importance of building a sufficiently large facility initially that allows room for growth. The model assumes production volumes achieved after increasing production by $33 \%$ for each of the 3 initial years followed by a $3 \%$ annual growth up to yr 15 . Construction costs are kept at a minimum when assuring that the facility can handle growth for up to $15 \mathrm{yr}$. A processing facility that is built for producing $6,804 \mathrm{~kg}(15,000 \mathrm{lb})$ of Cheddar would cost around $\$ 168,200$. If the entrepreneur initially builds a facility that is only large enough to produce $3,402 \mathrm{~kg}(7,500 \mathrm{lb})$ and then realizes a need to double in size to be profitable, the construction cost could increase to as much as $\$ 128,700+\$ 168,200=$ $\$ 296,900$, with additional costs for aging facilities and equipment. Thus, proper business planning before construction is essential. It is the experience of the authors that initially building too small a processing facility is a common mistake exhibited by artisan cheese makers. The numbers in the "cost per pound produced" columns are obtained by dividing the facility costs by pounds produced in yr 15. They are not an actual annual cost to be paid in a single year and are included to demonstrate the effect of economies of scale in building a facility. These economies are particularly evident for the processing facility. Note that costs in Table 5 do not include purchase of land or expenses related to building milk production facilities, such as milking parlor and farm.

When cheeses are aged in vacuum-packed or waxed formats, aging rooms can be very simple because only air temperature needs to be controlled. In contrast, naturally rinded cheeses must be aged in temperature-, humidity-, and air flow-controlled environments. This model assumes construction of the latter type of aging facility. As can be seen from the scenarios, construction of aging rooms would add approximately $25 \%$ to the processing facility construction cost.

\section{Equipment Costs}

Equipment needed for the 4 scenarios are summarized in Table 6 . Artisan cheese makers can deal with production increases in 2 ways: keeping the existing equipment and processing more frequently or increas- 
Table 5. Size and construction cost of processing facility and cheese aging facility

\begin{tabular}{|c|c|c|c|c|c|c|c|c|}
\hline Scenario $^{1}$ & \multicolumn{2}{|c|}{ Production volume $^{2}(\mathrm{~kg})$} & \multicolumn{3}{|c|}{ Production facility ${ }^{3}$} & \multicolumn{3}{|c|}{ Aging facility } \\
\hline 2 & $6,804(15,000 \mathrm{lb})$ & 9,701 & 104.2 & 168,200 & 17.34 & 43.7 & 36,700 & 3.78 \\
\hline 3 & $13,608(30,000 \mathrm{lb})$ & 19,401 & 136.2 & 219,900 & 11.33 & 87.4 & 49,300 & 2.54 \\
\hline 4 & $27,216(60,000 \mathrm{lb})$ & 33,803 & 178.1 & 287,400 & 7.41 & 174.8 & 74,500 & 1.92 \\
\hline
\end{tabular}

${ }^{1}$ Four scenarios differed based on annual production capacity; Cheddar cheeses aged for $150 \mathrm{~d}$ were produced in each scenario.

${ }^{2}$ Used as processing variable in scenarios; 3-yr scale-up target volume.

${ }^{2}$ Processing area excluding aging facility or any retail space.

${ }^{3}$ Based on pounds produced by yr 15 .

ing the size of the cheese-making equipment. For the first 3 scenarios, the cheese makers processed between $3,402 \mathrm{~kg}(7,500 \mathrm{lb})$ and $13,608 \mathrm{~kg}(30,000 \mathrm{lb})$ while still using a batch pasteurizer that doubled as a cheese vat; they were processing up to $3 \mathrm{~d}$ per week. In scenario 4 , the annual production has reached a level where batch pasteurization was no longer feasible. Instead, this processor utilized an HTST unit and a separate cheese vat. Cheese makers typically try to avoid HTST units for several reasons: cost of equipment, complexity of operation, need for a pasteurizer license that requires practical HTST work experience, and the need to install cleaning-in-place (CIP) systems. It is evident from scenario 4 that the HTST unit and CIP system significantly increased overall equipment cost. Although production volume (yr 15) increased 8-fold between $4,850 \mathrm{~kg}(10,695 \mathrm{lb})$ and $33,804 \mathrm{~kg}(74,544$ $\mathrm{lb}$ ), equipment cost only increased around 2.5 times. To make this easier to evaluate, we also presented equipment cost in terms of costs per pound produced (bottom of Table 6 and in Table 5). The reason the equipment costs only increased by 2.5 -fold over this range is that the cost of small equipment is often close to that of larger scale equipment. Note that equipment cost per amount of cheese produced was actually lower when adding production days to handle the increased volume (scenario 3) instead of investing in the HTST pasteurizer and CIP cleaning systems. This indicates that a large production volume is needed to justify scale-up to HTST equipment. Several factors affect equipment prices. The model assumed purchase of new equipment. Currently, more used small-scale equipment is becoming available. Much of the small-scale equipment is produced internationally (Europe or China). Thus, monetary exchange rates affect purchase prices. Cheese types also affect equipment requirements; for example, Cheddar does not require a brine tank, and soft cheeses do not require a cheese press. Similar to processing facility size, it is important to purchase a pasteurizer that is large enough to allow for increased production volume. The values indicated for pasteurizer size in Table 6 allow for production increases over $15 \mathrm{yr}$. The pasteurizer is the single largest equipment expense. It is recommended practice to ask the local inspector to review the equipment specifications before ordering. The justification that a pasteurizer was licensed for use in one state does not correctly indicate that it will be licensed in another state. In an attempt to save money, some entrepreneurs have chosen not to purchase a pasteurizer. It is important to understand that all raw milk cheeses must be aged for at least 60 d. In contrast, fresh pasteurized milk cheeses can be sold almost immediately, helping with cash flow and lowering aging expenses. Thus, not having a pasteurizer limits options for artisan cheese makers. Cheese vats without automatic stirring are cheaper. However, cheese makers who initially try to save on stirring often end up retrofitting the vats with automatic stirring because of the hard physical labor involved in stirring.

\section{Operating Costs}

Operating costs for yr 15 are summarized in Figure 3. Specific costs used in the model, such as cost of rennet, salt, cultures, and packaging materials, are reported per liter of milk or kilogram of cheese in Table 3. Production and marketing or sales labor are 2 of the 3 major operating costs. Although production labor cost increased as production volume increased, sales and marketing labor were less tied to production volume. Sales and marketing labor varied little as total production volume increased. For the largest volume $[27,216$ $\mathrm{kg}(60,000 \mathrm{lb})$ of cheese/yr], a company relies more on distributors and less on direct customer sales. Direct customer sales are labor intensive, whereas cheese sold through distribution requires minimal labor input by the artisan company.

As stated in the introduction, artisan cheese makers frequently fail to pay themselves a wage. Instead, they treat potential end-of-year profits as salary. For 
Table 6. Equipment costs ( $\$$ unless otherwise noted) associated with 4 scenarios that differed based on annual production capacity

\begin{tabular}{|c|c|c|c|c|}
\hline Equipment & \multicolumn{4}{|c|}{ Production capacity by yr 15} \\
\hline $\mathrm{LTLT}^{\prime} \mathrm{HTST}^{1}$ & 34,147 & 34,147 & 36,548 & 100,000 \\
\hline Size of pasteurizer & $900 \mathrm{~L}(240 \mathrm{gal})^{2}$ & $900 \mathrm{~L}(240 \mathrm{gal})^{2}$ & $1,210 \mathrm{~L}(320 \mathrm{gal})^{2}$ & $2,420 \mathrm{~L} / \mathrm{h}(640 \mathrm{gal} / \mathrm{h})^{3}$ \\
\hline Cheese vat & 0 & 0 & 0 & 6,000 \\
\hline Cheese molds & 3,002 & 3,002 & 5,031 & 10,060 \\
\hline Pumps and piping & 3,900 & 3,900 & 3,900 & 6,000 \\
\hline Refrigeration units (incubator) & 3,000 & 3,000 & 3,000 & 3,000 \\
\hline Packaging & 1,000 & 1,000 & 1,000 & 2,000 \\
\hline Milk transportation & 1,000 & 1,000 & 1,000 & 1,000 \\
\hline Whey management & 500 & 500 & 500 & 4000 \\
\hline Company vehicle & 20,000 & 20,000 & 20,000 & 20,000 \\
\hline Yr 15 capacity ( $\$ / \mathrm{kg}$ produced) & 22.29 & 11.16 & 5.80 & 7.91 \\
\hline
\end{tabular}

${ }^{1}$ LTLT $=$ low-temperature, long-time or batch pasteurizer; HTST = high-temperature, short-time pasteurizer.

${ }^{2}$ Size of LTLT unit.

${ }^{3}$ Capacity of HTST unit.

accounting and tax purposes, it is important to allocate a salary for the owner and owner's family, and end-ofyear profits can then be reinvested in the company.
Raw milk cost is directly linked to production volume and cheese yield. High-moisture cheeses have greater yield than hard cheeses and thus require less milk. It is

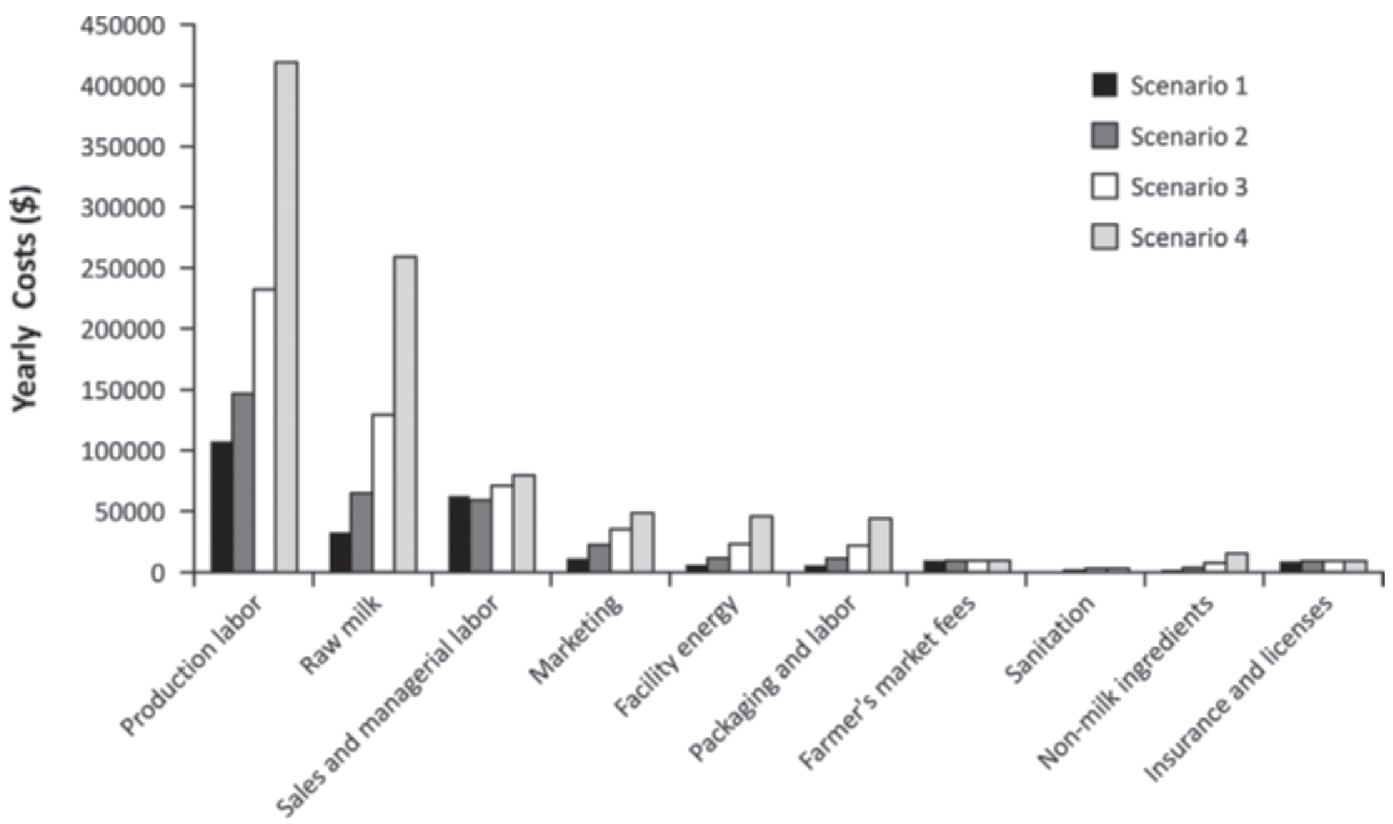

Operating Cost Variables

Figure 3. Production costs (in yr 15) for Cheddar cheese production. For all scenarios, Cheddar cheese was produced at a yield of $10 \%$ and aged for $150 \mathrm{~d}$. Scenarios 1 to 4 had total cheese production volumes, by yr 3, of 3,402 $\mathrm{kg}(7,500 \mathrm{lb}), 6,804 \mathrm{~kg}(15,000 \mathrm{lb}), 13,608 \mathrm{~kg}$ (30,000 $\mathrm{lb})$, and $27,216 \mathrm{~kg}(60,000 \mathrm{lb})$, respectively. 
Table 7. Start-up costs $(\$)$ and yr 1 operating costs $(\$)$ for facility producing Cheddar cheese aged for $150 \mathrm{~d}$

\begin{tabular}{|c|c|c|c|c|}
\hline \multirow[b]{2}{*}{ Cost } & \multicolumn{4}{|c|}{ Production $(\mathrm{kg})$} \\
\hline & 3,402 & 6,804 & 13,608 & 27,216 \\
\hline Facility & 128,700 & 168,200 & 219,900 & 287,400 \\
\hline Aging room & 30,400 & 36,700 & 49,300 & 74,500 \\
\hline Equipment & 108,148 & 108,148 & 112,578 & 261,974 \\
\hline Year 1 production costs & 65,245 & 107,411 & 324,315 & 620,094 \\
\hline Total & 332,493 & 420,459 & 706,093 & $1,243,968$ \\
\hline
\end{tabular}

important to realize that raw milk is a major component of the costs of goods sold. Cow milk is significantly cheaper than goat and sheep milks, yet artisan cow, goat, and sheep milk cheeses sell for close to the same retail price. Thus, we can conclude that profitability is easier to achieve for cow milk cheese than for the other types.

In addition to the initial investment in building and equipment, a lag phase occurs as production is scaled up and inventory is created. Therefore, a cheese company must prepare to cover substantial operating costs for an extended period until positive net revenue is achieved. An estimate of start-up costs, including operating capital for the first year of production, is summarized in Table 7.

\section{CONCLUSIONS}

This study did not address potential revenue streams, which vary considerably according to the types of cheese produced and marketing approaches. Thus, the study is not sufficient to assess the viability of a business. However, the data demonstrate the large initial investment required to launch an artisan cheese company. Critical to successful start-ups is access to sufficient capital to cover these costs. Few traditional banks currently lend money for such start-ups. Instead, entrepreneurs obtain funding from a combination of grants, economic development agencies, municipalities, and community banks. These nontraditional funding sources all require valid business plans. This study helps complete the cost components of such business plans. As with any model, many assumptions and estimates, as shown in Tables 2,3 , and 4 , were made in utilizing this business tool. This model is meant to mimic reality given this set of assumptions. With that in mind, innumerable events in real life could change estimates of start-up and operating costs.

\section{ACKNOWLEDGMENTS}

The authors thank Neville McNaughton (CheezSorce, St. Louis, MO) for his assistance with calculating aging room size and cost; Harold Schuller (C. van t'Riet Dairy Technology, DuBois, PA) for his equipment cost estimates; and Richard Chin (Covert Engineers, Portland, OR) for building cost estimates.

\section{REFERENCES}

Ahearn, M., G. D. Hanson, and R. Dubman. 1987. Financial performance of specialized dairy farms. Agric. Information Bulletin No. 519. USDA Economic Research Service, Washington, DC.

Axtell, B., P. Fellows, L. Gedi, H. Lubin, R. Musoke, and P. OtiBoateng. 2008. Setting Up and Running a Small-Scale Dairy Processing Business. P. Fellows and B. Axtell, ed. CTA Midway Technology, Wageningen, the Netherlands.

Becker, K. M., R. L. Parsons, J. Kolodinsky, and G. N. Matiru. 2007. A cost and returns evaluation of alternative dairy products to determine capital investment and operational feasibility of a smallscale dairy processing facility. J. Dairy Sci. 90:2506-2516.

Erba, E. M., R. D. Aplin, and M. W. Stephenson. 1997. Labor productivities and costs in 35 of the best fluid milk plants in the United States. Department of Agricultural, Resource and Managerial Economics, College of Agriculture and Life Sciences, Cornell University, Ithaca, NY.

Internal Revenue Service. 2010. How to depreciate property. IRS Publication No. 946. Accessed Jan. 10, 2013. http://www.irs.gov/ publications/p946/index.html.

Internal Revenue Service. 2011. Self-employment tax, Social Security and Medicare taxes. Accessed Jan. 10, 2013. http://www.irs.gov/ businesses $/$ small $/$ article $/ 0, i d=98846,00 . h t m l$.

Nicholson, C., and M. W. Stephenson. 2007. Financial performance value-added dairy operations in New York, Vermont and Wisconsin. Accessed Jan. 10, 2013. http://purl.umn.edu/9732.

Papadatos, A., A. M. Berger, J. E. Pratt, and D. M. Barbano. 2002 A nonlinear programming optimization model to maximize net revenue in cheese manufacture. J. Dairy Sci. 85:2768-2785.

Reed, B., L. J. Butler, and E. Rilla. 2011. Farmstead and Artisan Cheeses: A Guide to Building a Business. 1st ed. Agricultural and Natural Resources, Communication Services, University of California, Davis.

Sakovitz-Dale, J. 2006. Vermont farmstead cheese marketing study. Vermont Farm Viability Enhancement Program. Accessed Jul. 12, 2013. http/www.vhcb.org/pdfs/farmsteadcheesereport.pdf 